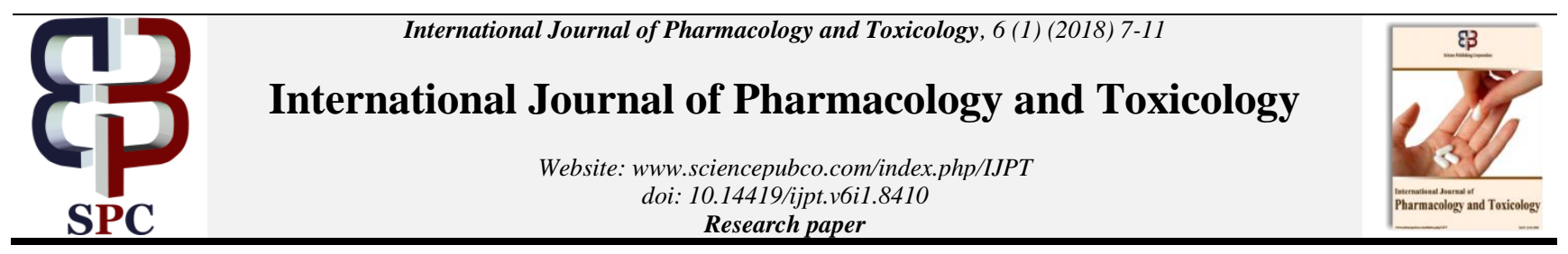

\title{
Anti-inflammatory potentials, membrane stabilizing and xanthine oxidase inhibitory activities of Clerodendrum volubile ethanolic leaf extract on carragenaan- induced inflammation in rats
}

\author{
O. Olarenwaju ${ }^{1}$, J. T. Apata ${ }^{2}$, B. A. Akinpelu' ${ }^{2}$, R. O. Akomolafe4, I. A. Oyemitan', \\ F. T. Asaolu' ${ }^{2}$ M. O. Ologe ${ }^{5}$, E. O. Iwalewa ${ }^{3 \text {, }}$ \\ ${ }^{1}$ Department of Pharmacology, Faculty of Pharmacy, Obafemi Awolowo University, Ile-Ife \\ ${ }^{2}$ Department of Biochemistry, Faculty of Sciences, Obafemi Awolowo University, Ile-Ife \\ ${ }^{3}$ Department of Pharmacology and Therapeutics, Faculty of Basic Medical Sciences, University of Ibadan, Ibadan \\ ${ }^{4}$ Department of Physiological Sciences, Faculty of Basic Medical Sciences, Obafemi Awolowo University, Ile-Ife \\ ${ }^{5}$ Department of Pharmacology and Therapeutics, Faculty of Basic Medical Sciences, University of Ilorin, Ilorin \\ *Corresponding author E-mail: eoiwalewa@yahoo.com
}

\begin{abstract}
The folkloric use of Clerodendrum volubile P Beauv (Verbenaceae) for treatment of inflammatory conditions in the Southern part of Nigeria has been reported. The anti-inflammatory action of the ethanolic leaf extract on carrageenan-induced rat paw oedema, lipoxygenase and xanthine oxidase inhibitory effects, and membrane stabilizing potential were evaluated. The extract reduced carrageenan-induced rat paw oedema in a dose dependent manner compared to control group. C. volubile inhibited xanthine oxidase activity in a dose - dependent manner; at $0.5 \mathrm{mg} / \mathrm{ml}$ it exhibited maximum inhibitory activity of $95.48 \%$ while the standard drug, allopurinol exhibited $70 \%$ inhibition. The extract significantly inhibited lipoxygenase activity, with highest activity at $0.4 \mathrm{mg} / \mathrm{ml}$ while Quercetin showed maximum inhibition of the enzyme at $0.1 \mathrm{mg} / \mathrm{ml}$. The extract and Acetaminophen exhibited maximum membrane stabilizing activity of $91.85 \pm 0.50 \%$ and $94.32 \pm 0.32 \%$ at $2.5 \mathrm{mg} / \mathrm{ml}$ respectively. These findings provide justification for the traditional use of $C$. volubile in inflammatory conditions.
\end{abstract}

Keywords: Antiinflammatory; Clerodendrum volibule; lipoxygenase; rats; xanthine oxidase.

\section{Introduction}

Inflammation is a major and complex reaction of the body against infection and tissue injury. It consists of recruitment and activation of leukocytes and plasma proteins at the site of infection to eliminate the infectious agent (Kindt et al., 2004). Diseases and disorders are manifested through chronic inflammatory responses as the body recognizes the injury when the repair the damage done is left to degenerate (Iwalewa et al., 2007). Therefore, in order to develop a therapeutic remedy from medicinal plant relating to the disease or disorder they affect, toxicological and pharmacological profile of the agent needs thorough evaluation.

Clerodendrum volubile has been used in the treatment of different forms of ailments such as arthritis, rheumatism, dropsy, swellings, oedema, and gout and to aid labour in pregnant women but there is no scientific information on its toxicity and anti- inflammatory profiles. Recently, Fred-Jaiyesimi and Adekoya (2012) also examined the anti-inflammatory activity of this plant. This study was therefore designed to investigate the acute anti-inflammatory effects of C. volubile extract on albino rats hind paw oedema induced by carrageenan and to further expanciate its mechanism through in-vitro lipoxygenase and xanthine oxidase inhibitory assays, since most of the disorders, it affects in folklore medicine are inflammatory induced.

\section{Materials and methods}

\subsection{Collection and identification of plant materials}

Fresh leaves of Clerodendrum volubile were collected from Ile-Ife, Osun State and authenticated in Ife herbarium, Obafemi Awolowo University, Ile-Ife, Osun State.

\subsection{Preparation of alcoholic extracts}

The leaves of $C$. volubile plants were harvested and sun-dried. The dried leaves were grounded to powder using manual grinder and $500 \mathrm{~g}$ of the powdered plant materials were soaked in $70 \%(\mathrm{~V} / \mathrm{v})$ ethanol for $48 \mathrm{~h}$. The marc was exhaustively extracted with more $70 \%$ ethanol, the filtrate was filtered using Whatman filter paper and concentrated to dryness in vacuo at $40^{\circ} \mathrm{C}$ under reduced pressure to obtain the crude ethanolic extract.

\subsection{Animals}

Rats of either sex, weighing between $150-200 \mathrm{~g}$ were used. The animals were maintained at $25+1^{\circ} \mathrm{C}$ under natural $12 \mathrm{~h}$ daylight/ night conditions for at least 5 days before the experimental procedures. 
All the animals were fed with standard diet in the Department of Pharmacology Animal House, and water was given ad libitum. The "principle of laboratory animal care" (NIH publication No. 85-23) guidelines and procedures were followed throughout this study (NIH publication revised, 1985).

\subsection{Drugs}

The following drugs were used during the experiment: Carragenaan (Sigma), Disprin ${ }^{(\mathrm{R})}$ Acetylsalicylic acid (Reckiti-Benckiser), Allopurinol (Sigma), Ethanol 99\% (Analar Grade), Quercetin (Sigma), Panadol $^{(\mathrm{R})}$ Acetaminophen (Emzor Pharmaceuticals).

\subsection{Carrageenan-induced rats paw oedema}

Twenty-five (25) adult Wistar albino rats (150-200 g) were divided into five groups of five rats each. The animals were given the following treatments the first day-after period of acclimatization;

Group A - distilled water - animal in this group received $2 \mathrm{ml} / \mathrm{kg}$ body weight per day.

Group B - (Extract treated) - Animal in this group received 250 $\mathrm{mg} / \mathrm{kg}$ of ethanolic extract of C. volubile.

Group C - (Extract treated) - Animal in this group received $500 \mathrm{mg} / \mathrm{kg}$ of ethanolic extract of $C$. volubile.

Group D - (Extract treated) -Animal in this group received $1000 \mathrm{mg} / \mathrm{kg}$ of ethanolic extract of C. volubile.

Group E - (Extract treated) - Animal in this group received 100 $\mathrm{mg} / \mathrm{kg}$ of aspirin.

Inflammation was then induced using the carrageenan paw oedema model (Winter et al. 1962) after one hour of treatment. The inflammation was quantified by the difference of measurement of the volume of saline solution displaced by the paw prior to the administration of phlogistic agent $\left(\mathrm{V}_{0}\right)$ and $0,1,2,3$ and $4 \mathrm{~h}$ after $(\mathrm{Vt})$, using the modified form of plethysmometer. Each measurement was the average of two readings and also by using a loop of thread tied around the paw such that it was neither too loose nor too tight. The length of the thread around the paw was also measured with a ruler and rounded off to the nearest centimeter.

\subsection{In vitro anti-inflammatory activity}

a) In vitro Lipoxygenase Inhibitory Assay

Lipoxygenase inhibitory activity of plant extracts with linoleic acid as a substrate was measured with a UV-VIS spectrophotometer (LABTRONICS, Model LT-290, Single Beam, England) as reported by Konatéet al. (2011) with some modifications, Plant extracts were screened for lipoxygenase inhibitory activity at various concentrations $(0.1-0.5 \mathrm{mg} / \mathrm{ml})$. The mixture assay consisted of 150 $\mu 1$ phosphate buffer (1/15 M, pH 7.5), $50 \mu \mathrm{l}$ of each extracts solution and $50 \mu$ l enzyme solution $(0.28 \mathrm{U} / \mathrm{ml}$ in the phosphate buffer) The reaction was initiated by adding $250 \mu$ l of substrate solution $(0.15 \mathrm{mM}$ in water). Enzymatic kinetic was recorded at $234 \mathrm{~nm}$ for 2 min. Negative control was prepared and contained $1 \%$ (v/v) methanol solution without extract solution. Quercetin, which was known to inhibit lipoxygenase was used as a standard (positive control) at various concentrations $(0.1-0.5 \mathrm{mg} / \mathrm{ml})$. All experiments were performed in triplicate. Lipo-oxyoxgenase inhibitory activity was calculated using the expression below:
$(\%)$ inhibition $=(1-\mathrm{B} / \mathrm{A}) \times 100$

Where $\mathrm{A}$ is the change in absorbance of the assay without the extracts (negative control) and B is the change in absorbance of the assay with the extracts. Lipoxygenase inhibitory activity was expressed as the percentage inhibition of lipoxygenase.

b) In vitro Xanthine Oxidase Inhibition Assay

Xanthine oxidase inhibition activity of plants extract with xanthine as the substrate was measured by a spectrophotometer (LABTRONICS, Model LT-290, Single Beam, England) as reported by Konaté et al. (2011) with some modifications, Extracts were directly dissolved in phosphate buffer-MeOH [1\% (v/v)] and screened for xanthine oxidase inhibitory activity at various concentrations (0.1-0.5 $\mathrm{mg} / \mathrm{ml})$. The mixture assay consisted of $150 \mu \mathrm{l}$ phosphate buffer (1/15 M, pH 7.5), $50 \mu \mathrm{l}$ fraction solution and $50 \mu 1$ enzyme solution $(0.28 \mathrm{U} / \mathrm{ml}$ in the phosphate buffer). The reaction was initiated by adding $250 \mu \mathrm{l}$ of substrate solution $(0.15 \mathrm{mM}$ in water). Enzymatic kinetic was recorded at $295 \mathrm{~nm}$ for $02 \mathrm{~min}$. Negative control was prepared and contained $1 \%(\mathrm{v} / \mathrm{v})$ methanol solution without extract solution. Allopurinol a well-known inhibitor of xanthine oxidase was used as a positive control at various concentrations (0.1-0.5 $\mathrm{mg} / \mathrm{ml}$ ). All experiments were performed in triplicate. Xanthine oxidase inhibitory activity was calculated using the expression below:

$(\%)$ inhibition $=(1-\mathrm{B} / \mathrm{A}) \times 100$

Where A is the change in absorbance of the assay without the extracts (negative control) and $\mathrm{B}$ is the change in absorbance of the assay with the extracts. Xanthine oxidase inhibitory activity was expressed as the percentage inhibition of xanthine oxidase.

c) Membrane stabilizing assay

The membrane stabilizing activity assay was carried out as previously described (Sadique et al., 1989; Oyedapo et al., 2004) using $2 \%$ (v/v) human erythrocyte suspension while Acetaminophen was used as standard drug. The assay mixtures consisted of $2 \mathrm{ml}$ of hyposaline $(0.25 \% \mathrm{w} / \mathrm{v})$ sodium chloride, $1.0 \mathrm{ml}$ of $0.15 \mathrm{M}$ sodium phosphate buffer, $\mathrm{pH} 7.4,0.5 \mathrm{ml}$ of $2 \%(\mathrm{v} / \mathrm{v})$ human erythrocyte suspension, $0.0-1.0 \mathrm{ml}$ of drugs (standard/extracts) and final reaction mixtures were made up to $4.5 \mathrm{ml}$ with isosaline. Drugs were omitted in the blood control, while the drug control did not contain the erythrocyte suspension. The reaction mixtures were incubated at $56^{\circ} \mathrm{C}$ for $30 \mathrm{~min}$ on a water bath followed by centrifugation at $5000 \mathrm{rpm}$ on Gallenkamp Bench Centrifuge for $10 \mathrm{~min}$ at room temperature. The absorbance of the released heamoglobin was read at $560 \mathrm{~nm}$. The percentage membrane stability was estimated using the expression:

$100-[($ Abs of test drug-Abs of drug control) $]$ x 100 (Abs of blood control)

Where the blood control represents $100 \%$ lysis or zero percent stability.

\section{Results}

\subsection{Anti-inflammatory properties of Clerodendrum vol- ubile}




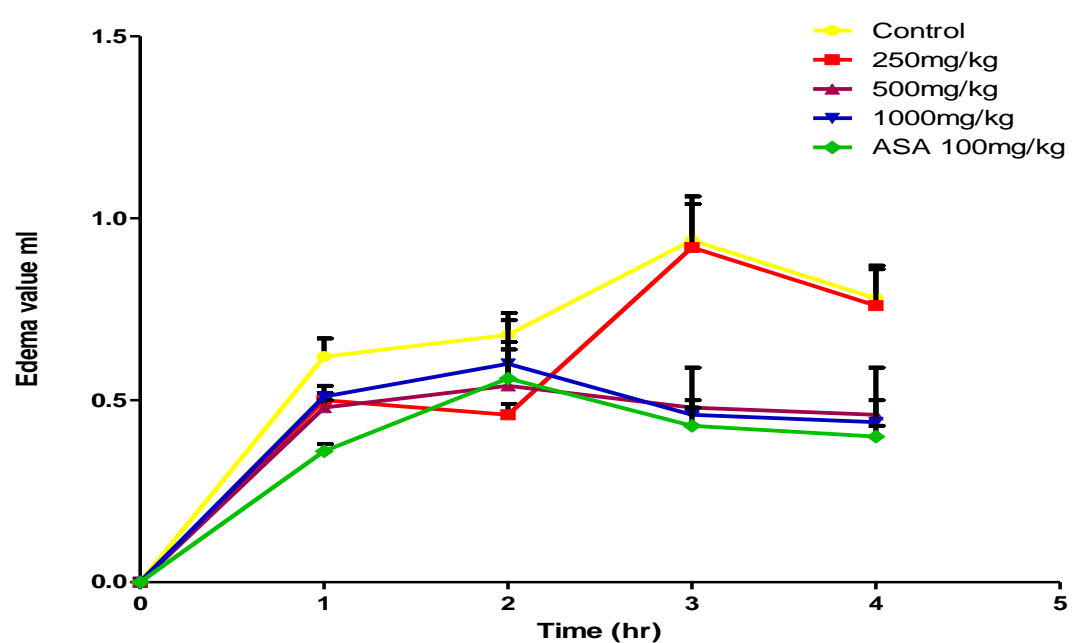

Fig. 1: Evaluation of Paw Volume in Carrageenan Induced Oedema in Ethanolic Extract of C. Volubile $(250 \mathrm{mg} / \mathrm{kg}, 500 \mathrm{mg} / \mathrm{kg}, 1000 \mathrm{mg} / \mathrm{kg})$, Aspirin $(100 \mathrm{mg} / \mathrm{kg}$ ) Treated Groups Reduced Paw Volume Change in Comparison to Control Group (Vehicle Treated Group).the Data Represent Mean \pm S.E.M of 5animals from 3 to $4 \mathrm{H}$ Curves of the Plant Extract 500; $1000 \mathrm{mg} / \mathrm{kg}$ are Significantly Different from Control.

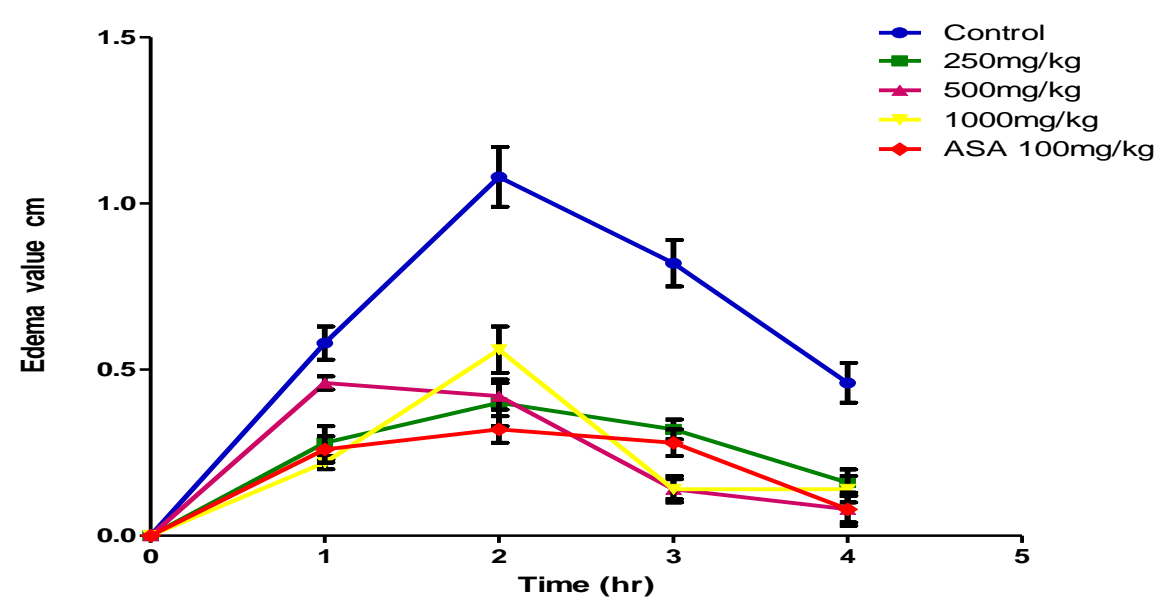

Fig. 2: Evaluation of Paw Diameter in Carrageenan Induced Oedema in Ethanolic Extract of C. volubile (250 mg/kg, $500 \mathrm{mg} / \mathrm{kg}, 1000 \mathrm{mg} / \mathrm{kg})$, Aspirin (100 $\mathrm{mg} / \mathrm{kg}$ ) Treated Groups Reduced Paw Volume Change in Comparison to Control Group (Vehicle Treated Group). The Data Represent Mean \pm S.E.M of 5animals. From 3 to $4 \mathrm{H}$ Curves of the Plant Extract at 500 and $1000 \mathrm{mg} / \mathrm{kg}$ were significantly different from Control.

\subsection{Lipoxygenase and Xanthine oxidase inhibitory as- says}

Table 1: Inhibitory Effect of $C$. volubile Leaf Extract on Xanthine Oxidase and Lipoxygenase

\begin{tabular}{lccccc}
\hline & \multicolumn{3}{c}{ Xanthine Oxidase } & \multicolumn{3}{c}{$\begin{array}{c}\text { Lipoxygenase } \\
\text { C. volubile } \\
\text { Conc. }\end{array}$} & $\begin{array}{c}\text { C. volubile } \\
\text { mg/ml }\end{array}$ & $\begin{array}{c}\text { Allopurinol } \\
\text { inhibition } \% \text { inhibition }\end{array}$ & $\begin{array}{c}\text { Conc. } \\
\mathrm{mg} / \mathrm{ml}\end{array}$ & $\begin{array}{c}\text { \% inhibition } \\
\% \text { inhibition }\end{array}$ \\
\hline 0.1 & 54.54 & 60 & 0.1 & 70 & 96.83 \\
0.2 & 72.72 & 50 & 0.2 & 60 & 98.4 \\
0.3 & 86.36 & 50 & 0.3 & 50 & 93.75 \\
0.4 & 90.91 & 60 & 0.4 & 90 & 92.00 \\
0.5 & 95.48 & 70 & 0.5 & 80 & 96.85 \\
\hline
\end{tabular}

C. volubile inhibited xanthine oxidase activity in a dose -dependent manner and at $0.5 \mathrm{mg} / \mathrm{ml}$ exhibited maximum inhibitory activity of $95.48 \%$. C. volubile compared favourably with the standard drug, allopurinol, which exhibited $70 \%$ inhibitory activity at $0.5 \mathrm{mg} / \mathrm{ml}$. C. volubile extract significantly inhibited the lipoxygenase activity. Its inhibitory action ranged from $70 \%$ to $90 \%$, though not in dosedependent manner, with highest anti-lipoxygenase activity of $90 \%$ at $0.4 \mathrm{mg} / \mathrm{ml}$ while the standard drug quercetin showed maximum inhibition of $96.85 \%$ at a concentration of $0.5 \mathrm{mg} / \mathrm{ml}$. At all concentrations used, quercetin inhibited lipoxygenase better than $C$. volubile extract.

\subsection{Membrane stabilizing activity of Clerodendrum vol ubile}

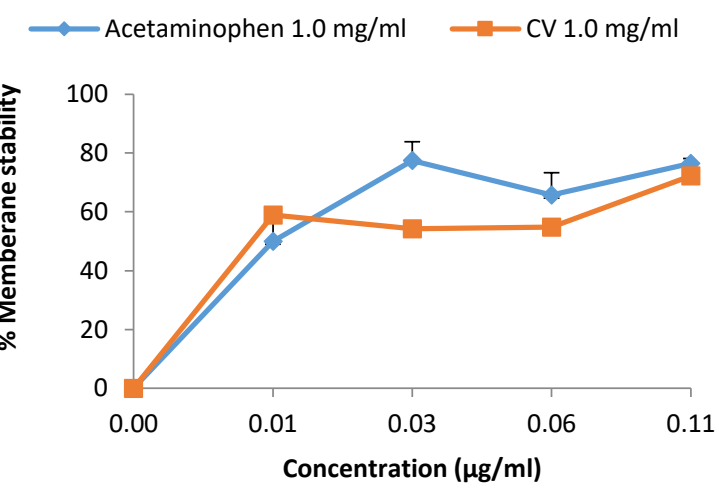

Fig. 3: Evaluation of Membrane Stabilizing Activity of Acetaminophen and C. volubile Leaf Extract at $1.0 \mathrm{mg} / \mathrm{ml}$. the Data Represent Mean \pm S.E.M of Readings. 


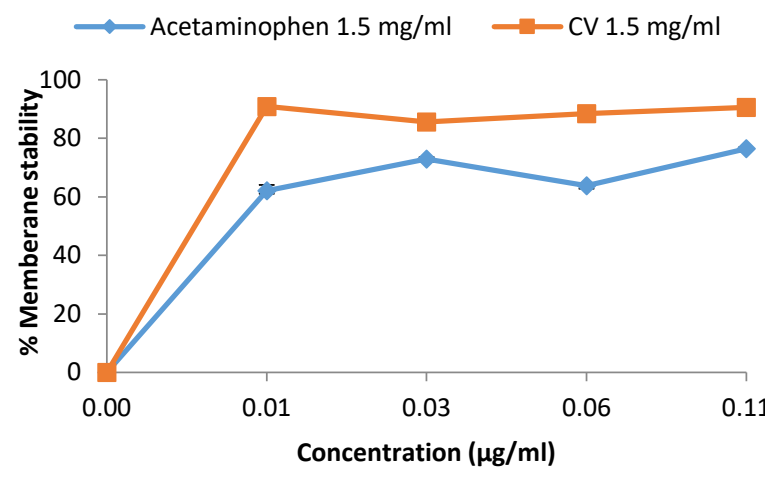

Fig. 4: Evaluation of Membrane Stabilizing Activity of Acetaminophen and C. volubile Leaf Extract at $1.5 \mathrm{mg} / \mathrm{ml}$. The Data Represent Mean \pm S.E.M of Readings.

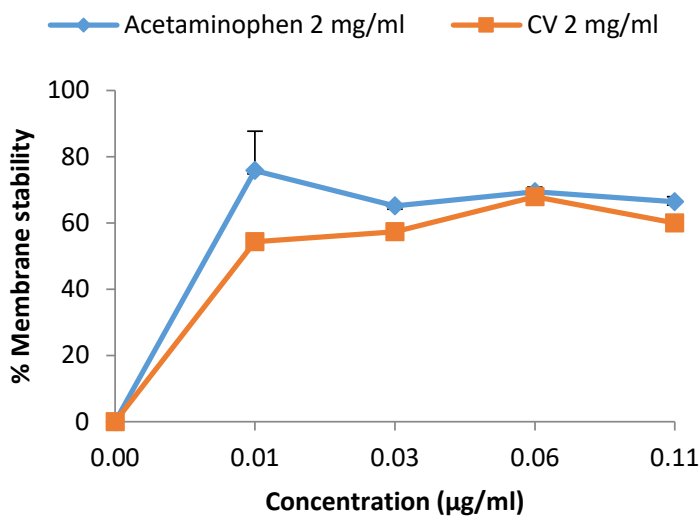

Fig. 5: Evaluation of Membrane Stabilizing Activity of Acetaminophen and C. volubile Leaf Extract at $2.0 \mathrm{mg} / \mathrm{ml}$. The Data Represents Mean \pm S.E.M of Readings.

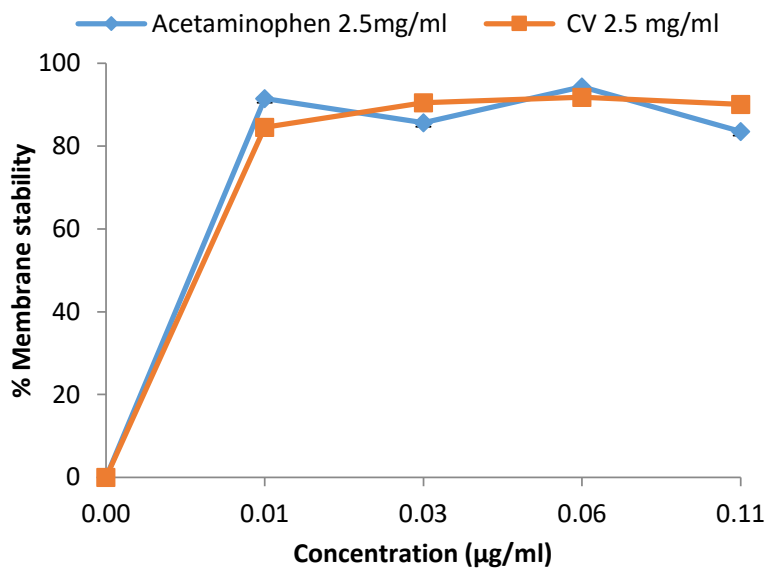

Fig. 6: Evaluation of Membrane Stabilizing Activity of Acetaminophen and C. volubile Leaf Extract at $2.5 \mathrm{mg} / \mathrm{ml}$. The Data Represent Mean \pm S.E.M of Readings.

The membranes stabilizing profiles of $C$. voluble leaf extract and acetaminophen (standard drug) on bovine erythrocytes exposed to both heat and hypotonic induced lyses are presented in Figures 3 6 . The extract exhibited a minimum membrane stability of $54.30 \pm$ $0.64 \%$ at $1.0 \mathrm{mg} / \mathrm{ml}$ and maximum activity of $91.85 \pm 0.50 \%$ at 2.5 $\mathrm{mg} / \mathrm{ml}$ while acetaminophen exerted maximum membrane stabilities of $50.00 \pm 8.03 \%$ and $94.32 \pm 0.32 \%$ at $1 \mathrm{mg} / \mathrm{ml}$ and $2.5 \mathrm{mg} / \mathrm{ml}$ respectively. However, in Figure 4 at the concentration of 1.5 $\mathrm{mg} / \mathrm{ml}, C$. volubile leaf extract showed a significant membrane stabilizing property than acetaminophen.

\section{Discussion}

The anti-inflammatory activity of the plant extracts was evaluated on manifestations accompanying the inflammatory reaction like oedema, increased vascular permeability and leukocyte migration into inflamed tissue. $C$. volubile extract reduced carrageenan- induced rats paw oedema in a dose dependent manner compared to control group from 2- $4 \mathrm{~h}$ (Figures 1 and 2) and there was no significant difference between the inhibition at $1000 \mathrm{mg} / \mathrm{kg}$ of $C$. voluble and aspirin $(100 \mathrm{mg} / \mathrm{kg})$. Carrageenan-induced inflammatory process is believed to be biphasic (Vinegar et al., 1969). The initial phase seen at the 1st hour is attributed to the release of histamine and serotonin (Cruckhon and Meacock, 1971). The second accelerating phase of swelling is due to the release of prostaglandin, bradykinin and lysozyme. It has been reported that the second phase of oedema is sensitive to both clinically useful steroidal and non-steroidal antiinflammatory agents (Katzung, 1998). Rats pre-treated with C. volubile extract showed a significant oedema inhibitory response $2 \mathrm{~h}$ following carrageenan injections. This suggests that $C$. volubile extract may act by suppressing the later phase of the inflammatory process by the inhibition of cyclooxygenase, the enzyme involved during the formation of prostaglandins. The in vitro effect of the extract on lipoxygenase and xanthine oxidase inhibitory assays supported the in vivo carrageenan-induced oedema pinpointing that prostaglandin's pathways are most affected. This further suggests that ethanolic extract of $C$. volubile leaves has an anti-inflammatory effect comparable to the standard drug, aspirin.

Inflammation is a physiological response process that is generated by the body in the event of injury, infection or irritation to guard the body and to hasten-up the recovery process. However, inflammation that is unchecked leads to chronic inflammatory disorders. Inflammation in injured cells is both initiated and maintained by the overproduction of prostaglandins and leukotrienes, which are produced by separate enzymatic pathways, viz the cyclo-oxygenase (COX) and lipoxygenase (LOX) pathways. Some of the anti-inflammatory drugs have been reported to inhibit the lipoxygenase pathway and some inhibit cyclooxygenase pathway thus, these two pathways are used for potential interventions against inflammation (Oliver, 2007; Krishanu et al., 2008). The lipoxygenase pathway has a role to play in the pathogenesis of inflammatory disorders like asthma thus increased activity of this pathway can aggravate asthmatic symptoms (Sharma and Mohammed, 2006; Mashima and Okuyama, 2015). Therefore, in this study the inhibition of the lipoxygenase pathway by $\mathrm{C}$. voluble is an indication that it can be useful in treatment of asthmatic patients. Inhibition of xanthine oxidase reduces the production of uric acid which relates to medical condition such as gout (Pacher et al., 2006). The administration of the extract may be useful for the management of gouty arthritic conditions since xanthine oxidase inhibition will prevent the generation of reactive oxygen species and the resulting inflammatory responses associated with the deposition of uric acid crystals in the joints and kidneys (Mohapatra et al., 2015).

Anti-inflammatory agents exert their effects through a variety of mechanisms that include stabilization of red blood cells exposed to hypotonic induced lyses. Plant-derived drugs were reported to contain principles that possess the ability to facilitate the stability of biological membranes when stressed (Sadique et al., 1989; Oyedapo et al., 2004).The study showed that the membrane stabilizing activities of $C$.voluble protected the stressed bovine erythrocyte membrane at all concentrations in this study and compared favorably with standard drug acetaminophen at all concentrations used. The membrane stabilization assay is a technique for the rapid screening of potential anti-inflammatory compounds based on their ability to inhibit heat-induced hemolysis of red blood cells (Brown et al., 1967). During inflammation, lysosomal hydrolytic enzymes are released causing damage to the surrounding organelles and tissues with variety of disorders occurring from the damage (Sadique et al., 1989). Drugs by stabilizing the membrane can prevent the rupture of the lysosomes and inhibit the release of lysosomal enzymes (Ignarro, 1971).The The erythrocyte's membrane serves as a model for lysosomal membrane since it was observed that several 
agents capable of releasing hydrolytic enzymes from lysosomes also injure erythrocytes (Ajayi et al., 2014). The stabilization of the membrane inhibits phospholipase $\mathrm{A}_{2}$ thus preventing the production and release of eicosanoids, which are involved in inflammation processes. This finding further buttresses the in vivo anti-inflammatory effect of the plant extracts. Therefore, it could be inferred that $\mathrm{C}$. voluble contained principles that were capable of stabilizing bovine red blood cell membrane exposed to heat and hypotonicinduced lyses and could serve as a useful therapy in management and treatment of inflammatory related diseases.

\section{Conclusion}

The results of this study provide valuable data on acute in vitro and in vivo anti-inflammatory effect of this plant. The ethanolic extract of the leaf of the plant suppressed carrageenan-induced inflammation. Since the plant extract stabilizes the membrane, it is likely to possess anti-inflammatory activity in gouty arthritis and asthmatic conditions. This indicates that the extract possesses anti-inflammatory activity which could justify its traditional use

\section{References}

[1] AjayiAM, TanayenJK, EzeonwumeluJOC, DareS, OkwanachiA, AdzuB, and Ademowo OGAnti-inflammatory, Anti-nociceptive and Total polyphenolic Content of Hydroethanolic Extract of Ocimum gratissimum L.Leaves Afr J Med Med Sci. 2014; 43(Suppl 1): 215224.

[2] Brown JH, Mackey HK and Rigglio DA.A Novel in vitro Assay for Anti-Inflammatory Agents Based on Stabilization of Erythrocytes. ExptalBiol Med. 1967; 125: 837. https://doi.org/10.3181/00379727. 125-32219.

[3] Crunkhon P, Meacock SER 1971: Mediators of inflammation induced in the rat paw by carrageenan. British Journal of Pharmacology 42: 392-402 https://doi.org/10.1111/j.14765381.1971.tb07124.x.

[4] Fred-Jaiyesimi, A. and Adekoya, Y. (2012) Pharmacognostic Studies and Antiinflammatory Activities of Clerodendrum volubile P Beauv Leaf International Journal of Phytomedicine 4, 414-418.

[5] Ignarro LJ. Effects of anti-inflammatory drugs on the stability of rat liver lysosomes in vitro. Biochem Pharmacol. 1971; 20: 2847-60. https://doi.org/10.1016/0006-2952(71)90196-1.

[6] Iwalewa, E.O., McGaw, L.J., Naidoo, V., Eloff, J.N. (2007) Inflammation: the foundation of diseases and disorders. A review of phytomedicines of South African origin used to treat pain and inflammatory conditions. African Journal of Biotechnology 6 (25): 2868-2885. https://doi.org/10.5897/AJB2007.000-2457.

[7] Katzung BG, 1998: Basic and Clinical Pharmacology. 7th ed. Stanford: Connecticut: pp. 578-579.

[8] Kindt,TJ, Goldsby, RA, Osborne, BA and Kuby, J.(2004), Kuby Immunology, 6th edition. New york: W.H. Freemann and company..

[9] Konaté, K. and Souza, A. (2010a). In vitro Antioxidant, Lipoxygenase and Xanthine Oxidase Inhibitory Activities of fractions from Cienfuegosiadigitata Cav., Sida alba L. and Sidaacuta Burn f. (Malvaceae). Pakistan Journal of Biological Sciences 13 (22): 10921098. https://doi.org/10.3923/pjbs.2010.1092.1098.

[10] Konaté, K., Souza, A., Thérèse, K.Y., Dibala, I.C, Barro, N., Rasolodimby, J.M. and Nacoulma, O.G. (2011). Phytochemical composition, Antioxidant and Anti-inflammatory potential of bioactive fractions from extracts of three medicinal plants traditionally used to treat liver diseases in Burkina Faso. International Journal of Phytomedicine 3: 406-415.

[11] Krishanu S, Krishnaraju AV, Satish AR, Mishra S, Trimurtulu G, Sarma KVS, Dey D and Raychaudhuri SP. A double blind, randomized, placebo controlled study of the efficacy and safety of 5-Loxin® for treatment of osteoarthritis of the knee. Arthrit. Res. Ther., 10, 2008, 85. https://doi.org/10.1186/ar2461.

[12] Mashima, R. and Okuyama, T. The role of lipoxygenases in pathophysiology; new insights and future perspectives. Redox Biology 6 (2015) 297-310. https://doi.org/10.1016/j.redox.2015.08.006.

[13] Mohapatra, S., Kabiraj, P., Agarwal, T., Asthana, S., Annamalai, N., Arsad, H., Siddiqui, M.H., Khursheed, A., 2015. Targeting jatropha derived phytochemicals to inhibit the xanthine oxidase \& cyclooxygenase-2: in silico analysis towards gout treatment. Int. J. Pharm. Pharm. Sci. 7, 360-363.
[14] Oliver, W. (2007) Inhibition of 5-Lipoxygenase product synthesis by natural compounds of plant origin. Planta Medica., 73: 1331-1357. https://doi.org/10.1055/s-2007-990242.

[15] Oyedapo OO, Akinpelu BA, Orefuwa SO (2004). Anti-inflammatory effect of Theobroma cacao, L. root extract. J. Trop. Med. Plants (Malaysia), 5(2): 161-166.

[16] Pacher, P., Nivorozhkin A. and Szabo, C. 2006. Therapeutic effect of xanthine oxidase inhibitors: Renaissance half a century after the discovery of allopurinol. Pharmacol. Rev., 58: 87-114.

[17] Sadique J, Al-Rqobah NA, Bughaith MF, El-Gindy AR (1989). The bioactivity of certain medicinal plants on the stabilization of RBC membrane system. Fitoterapia LX, 525-532.

[18] Sharma, J. N. and Mohammed, L.A. The role of leukotrienes in the pathophysiology of inflammatory disorders: Is there a case for revisiting leukotrienes as therapeutic targets? InflammoPharmacology 2006, 14(1-2): 10-16. https://doi.org/10.1007/s10787-006-1496-6.

[19] Vinegar R, Screiber W, Hugo R, 1969: Biphasic development of carrageenan oedema in rats. Journal of Pharmacology and Experiimental Therapeutics 166: 96-103.

[20] Winter, CA., Risley, EA and Nuss, CW., (1962) Carrageenan - induced oedema in the hind paw of the rat as an assay for anti - inflammatory drugs. Proceedings of the Society for Experimental Biology and Medicine 111:544-547. 